Warszawskie Studia Pastoralne UKSW

Rok XI 2016 Nr 4(33)

Ks. Dariusz Pater

\title{
SUFFERING IN THE LIFE OF MOTHER TERESA OF CALCUTTA
}

\begin{abstract}
"Suffering gives us the opportunity to conform ourselves to Jesus and become one with the cross. This is the most wonderful way to draw near to God". (Mother Teresa)
\end{abstract}

Suffering is a timeless topic. The oldest known records dedicated to human experiences and feelings have already addressed the issue of suffering. For many, suffering is an indicator of what is human, flawed, imperfect and difficult to accept. As a "misterium doloris", suffering makes us reflect, raises a number of questions and doubts, affects relationships with other people and God. The history of the Church shows a number of people whose everyday life was filled with their own and others' physical suffering that affected their decisions, guided them through life, shaped their hierarchy of values and attitude toward neighbors. A unique person who is and will be remembered in the hearts of people and the history of the last century, was Mother Teresa, a strong, wise, humble and fascinating woman who worked among the poorest of the poor, the sick, the disfigured and those rejected by society ${ }^{1}$. The suffering of others that she witnessed as well as her own ailments, appearing especially in the last stage of her life, brought her closer to God, and helped her pursue her unique work of helping the needy.

1 Cf. L. Maasburg, Matka Teresa. Cudowne historie, Poznań 2010, p. 7. 
Her service to others as a "tireless merciful mother of mankind" aroused the admiration of millions of people worldwide. For many, she has become a role model - for how to live with joy, understanding, compassion and love.

\section{A portrait of life painted with the suffering (life filled with painful experiences)}

Mother Teresa was born in Skopje on August 27, 1910 as Anjezë Bojaxhiu, the youngest of three children. She was called Ganxhe in the family, which meant rosebud ${ }^{3}$. Her parents were of Albanian origin, but the population of Skopje was very diversified, also in terms of religion. Mother Teresa's family was deeply Catholic; her parents regularly attended the church and acted as role models for their children. They sent their children to school, though the education of girls was not widespread in those days. Ganxhe learned willingly and with ease; she also engaged in the life of the parish by singing in the choir together with her sister ${ }^{4}$.

The family lived in peace and unity, and, because of their relatively high social status, helped the poor by hosting dinners for those in need; in this way, they taught their children to love others, do good and be sensitive to human misery. Observing the example of their parents, the children learned the importance of prayer and work. The father was the owner of a construction company, according to one source, or a trade company, according to some other; yet another source says he worked as a pharmacist. He was actively involved in the movement for the independence of Albania. Aged 42, he died in mysterious circumstances, which significantly deteriorated the financial status of the family.

${ }^{2}$ X. Lecoeur, Matka Teresa. Niezłomna w wierze, trans. E. Bekier, Warszawa 2006, p. 7.

3 Por. M. di Lorenzo, Matka Teresa. Blaski miłości, trans. M. Kubiak, Poznań 2004, p. 18.

4 Por. L. Gjergji, Matka Teresa. Miłość w czynach, trans. J. Kupka, Warszawa 2002, p. 18-19. 
At the end of her childhood, Ganxhe felt an irresistible desire to serve God in the religious life. The girl's mother, to whom the youngest daughter was very close, initially opposed her decision; however, she agreed eventually. Therefore, on September 25, 1928, Ganxhe said goodbye to her relatives, friends and the faithful of the parish, left Skopje and went to Rathfarnham near Dublin in Ireland to join the Order of the Missionary Sisters of Our Lady of Loreto ${ }^{5}$. In a short time, she was ready to set on a long journey to India to enter a two-year novitiate, which truly pleased her as she became interested in this country and wanted to get to know India after reading the letters of missionaries working in the Archdiocese of Calcutta. In December 1928, she arrived in Darjeeling after a journey lasting over a month ${ }^{6}$. The novitiate is a time of learning, intense prayer, reading books on spirituality, learning about the lives of saints, huge enthusiasm in helping others and involvement in the religious life. In 1931, after the period of the novitiate, Ganxhe made vows of poverty, chastity and obedience, and took the name of Teresa after Sister Therese of the Child Jesus, whose longing for missionary work inspired Ganxhe to pursue this path. A year later, she renewed temporary vows and on May 24, 1937 she professed perpetual vows.

According to the decision of her superiors, for nearly 20 years (1929-1948) Sister Teresa worked as a teacher of geography and history in the Virgin Mary high school for girls from wealthy homes in Entally (district of Calcutta), although there were also orphaned children who did not have to pay tuition. Over time, she became the principal of the institution ${ }^{8}$ and did not expect any revolutionary changes in her life. The day of September 10, 1946, however, changed the life of Sister Teresa. Travelling by train to Darjeeling for a retreat

${ }^{5}$ Cf. M. di Lorenzo, Matka Teresa. Blaski miłości, op. cit., p. 21.

6 Cf. M. Dhavamony, U źródeł duchowości Matki Teresy; teologiczna perspektywa, trans. K. Bronk, Kraków 2002, pp. 26-27.

7 Cf. M. di Lorenzo, Matka Teresa. Blaski miłości, op. cit., p. 24.

${ }^{8}$ Cf. Matka Teresa, Radość z kochania. Przewodnik życia duchowego na każdy dzień roku, trans. A. Kieturakis, Białystok 1997, p. 12. 
to the monastery of her Congregation, she heard Jesus, who asked her to dedicate her life to the poorest of the poor ${ }^{9}$. Mother Teresa called this event many times a "call within a call". She appealed to the Holy See for the privilege of exclaustration, i.e. life outside the religious house. She received such permission on August 8, 1948 from Pope Pius XII. Soon, she left the Congregation of Sisters of Loreto to carry out her ministry to the poor on the streets of Calcutta ${ }^{10}$.

Starting her new ministry, she asked for an Indian citizenship and finished a nursing course. She put on a modest white sari with a blue hem and a small cross hanging on her left shoulder, a clothing which was worn by the poorest women in India. She lived in Motijihil, a slum neighborhood, near her former school. She went out into the streets, visiting the poor, the sick, and teaching children the alphabet. She worked alone, but soon first vocations appeared and several girls joined Sister Teresa. Then the decision was made to found the Congregation of the Missionaries of Charity, which was allowed to work under diocesan law on October 7, 1950 ${ }^{11}$, and in 1956 the Congregation of the Affairs of Religious issued the document "Decretum Laudis" allowing the missionaries to work under pontifical law ${ }^{12}$. The basic rule of the Congregation is the service to the poorest, without expecting anything in return, through absolute poverty, abandonment of any goods, renunciation of private life, even letters and family visits. It is acceptable to have three sets of sari, a pair of sandals and a prayer book ${ }^{13}$.

Thanks to her generous ministry and the care for the most needy, Sister Teresa started to be called "mother". It was for slum dwellers'

9 Cf. X. Lecoeur, Matka Teresa. Niezłomna w wierze, op. cit., p. 34.

10 Cf. M. di Lorenzo, Matka Teresa. Blaski miłości, op. cit., p. 35; Matka Teresa, Radość z kochania. Przewodnik życia duchowego na każdy dzień roku, op. cit., p. 12; M. Białkowska, Świętość bez kompromisów, www.przewodnik-katolicki.pl/ Archiwum/2010/Przewodnik-Katolicki-34-2010/Wiara-i-Kosciol/Swietosc-bez-kompromisow [18.07.2016].

11 Cf. L. Gjergji, Matka Teresa, trans. A. Spurgjasz, Litonova 1994, pp. 142-143.

12 Cf. idem, Matka Teresa. Miłość w czynach, op. cit., pp. 33-34.

13 Cf. X. Lecoeur, Matka Teresa. Niezłomna w wierze, op. cit., p. 37. 
that she organized Homes for the Dying so that they could pass away with dignity; she founded Children's Homes, Mother's Homes, Elders' Homes and Lepers' Homes. She spread her ministry basically to the whole world, including the Vatican and Poland. The mission of Mother Teresa and her Congregation continues till this day, which seems particularly important as nowadays loneliness, rejection, feelings of abandonment, spiritual poverty and lack of love are much harder to remove than physical shortcomings or hunger for bread. Also, Mother Teresa herself often experienced "spiritual darkness", a state that she perceived as total loneliness and the feeling that God abandoned her, which may as well be the evidence of the ordinary moments of doubt, fear and uncertainty ${ }^{14}$. For her work and the work of all the sisters of the Congregation of the Missionaries of Charity, Mother Teresa was awarded honorary titles of many renowned universities, the highest state and international awards, including the John XXIII Peace Prize in 1971, and the Nobel Peace Prize in $1979^{15}$. She accepted them with gratitude on behalf of the poor, the hungry, the sick and the lonely. A unique award, which was especially valued by Mother Teresa, was the visit of the Holy Father John Paul II on February 3, 1986, who visited the sick and the dying in Nirmal Hriday together with the missionary, blessing each one of them ${ }^{16}$. Although the list of awards and honors granted to Mother Teresa for her work is very long, she was immune to the temptation of titles, honors, medals and awards, or meetings with statesmen. She called herself a little pencil in the hand of God, who thus fulfilled His work ${ }^{17}$.

Despite such great dedication of Mother Teresa, the sisters of the Congregation, or the Congregation of Brothers of the Missionaries of Charity, the problems of poverty, disease and suffering, hunger and social injustice did not disappear; however, the attitude of the

\footnotetext{
14 Cf. X. Lecoeur, Matka Teresa. Niezłomna w wierze, op. cit., p. 31. More on this topic cf. P. Murray, Matka Teresa. Kochałam Jezusa w ciemnościach, Łódź 2010.

15 Ibid, p. 25.

16 Cf. M. di Lorenzo, Matka Teresa. Blaski miłości, op. cit., pp. 94-95.

17 Cf. L. Maasburg, Matka Teresa. Cudowne historie, op. cit., p. 192.
} 
missionary demonstrates the enormous human potential and remarkable strength lying in one person, whose determination to act can change the world, even to a little extent. The greatness of Mother Teresa stemmed from her great love for Jesus which she showed by leaning over the hungry, the suffering and abandoned man, the nurturing of whom she treated as the literal touching of Christ.

\section{The experience of suffering and the call to serve the suffering}

Mother Teresa's desire to help neighbors stemmed from her experiences in the family home, where the poor were invited to the table, supported in disease, and no one in need returned home empty-handed. It was her mother who taught her that helping the needy should be done quietly. Throughout all the years spent in the family home and in the Congregation of Loreto, Sister Teresa did good by engaging in the spiritual life, but it was only after coming into the streets of Calcutta that she saw extreme poverty, naked, malnourished children, people dressed in rags, the sick and the dying in the streets, people living in slums, and muddy, dirty alleys ${ }^{18}$.

Mother Teresa treated the unexpected call of Jesus to help the poor as another manifestation of her vocation and left her structured and monastic life to follow Him and do His will. Sometimes she felt the temptation to return, but she never stepped back. She recognized the poor, the sick, the lonely and abandoned people as her new community. She did not fear that she would not cope with this mission, as she firmly believed in the support of Jesus. She held this conviction throughout all her life. Mother Teresa also passed on this conviction to her missionaries explaining that the words "I am thirsty", repeated many times by the crucified Christ, referred to the loving sacrifice of Himself for the service to the suffering. Therefore, the aim of the ministry of each sister should be the desire to quench the thirst of Christ, who became man. To remind the sisters about their ultimate mission, there is the writing "I am thirsty" in every chapel of the Missionaries of Charity, which is a physical symbol of the spiritual

${ }^{18}$ Cf. M. di Lorenzo, Matka Teresa. Blaski miłości, op. cit., p. 34. 
thirst of love, acceptance and the need to belong ${ }^{19}$, implemented with four absolute vows of poverty, chastity, obedience and love for the poor. Thus, the lives of the poor, the suffering and the rejected became part of the missionaries' lives.

The Congregation's rules have never been and are still not easy, but Sister Teresa assumed that a crude monastery-like daily schedule would help novices accept and implement the rules in their service. Each of the missionaries had to individually take care of their own clothes and hygiene, the importance of which was particularly emphasized by Mother Teresa. Also, it was the missionaries' duty to know spoken and written English; pray individually; participate in the Eucharist, common Adoration of the Blessed Sacrament, modest meals and daily meetings during which the sisters reported on the past day and set the agenda for the next day. On Sunday, the missionaries devoted themselves entirely to prayer, study and reflection. Adoration, prayer, meditation and spiritual reading supported the missionaries in doing selfless service to the poorest of the poor. What was crucially important in these rules, however, was the work they performed mostly in groups of two with a smile on their faces and joy in their hearts, traversing many kilometers on foot every day in the poorest alleys of Calcutta and the surrounding area in search of the sick and the most needy ${ }^{20}$. While they worked very hard, they did not get anything material in return, as missionaries did not receive any remuneration for their service ${ }^{21}$. Mother Teresa recommended that her sisters say a trustful prayer to the Heart of Mary and pray the rosary with love and devotion in any place and at any time. Sister Teresa herself always had a rosary in her hand and prayed it constantly. She developed the habit of praying already in the family home in Skopje and prayer was the source of everything for her throughout all her life.

\footnotetext{
19 Cf. Matka Teresa, Pójdź, bądź moim światłem, ed. B. Kolodiejchuk, Warszawa 2007, pp. 61-64.

20 Cf. G. de La Borie, Małe życie Matki Teresy, trans. J. Jędraszak, Ząbki 2003, pp. 56-57.

${ }^{21}$ Cf. L. Maasburg, Matka Teresa. Cudowne historie, op. cit., p. 40.
} 
In her tireless ministry, Mother Teresa found Christ in each person she encountered. The meeting of a dying, abandoned woman whose body was being eaten by rats and ants was a fateful event for Mother Teresa. Although the stench of the dying woman was repulsive, Sister Teresa drove the woman in her famous missionary wheelchair to the hospital, where she was expecting some help for the woman. She could not understand the callousness of the medical personnel who considered the state of the woman hopeless and unworthy of their attention. She discovered then that it is through such helpless people that Jesus calls "I am thirsty". The answer to the terrible situation of the dying people in the streets of Calcutta became the Home for the Dying Destitutes in Calcutta (Home of the Pure Heart) as well as and in other places of the world. Their aim was to restore the dignity of every human being, regardless of their race, ethnicity or even religion, because one can find traces of the Creator in everyone ${ }^{22}$. Therefore, the help to the poor living and dying in the streets became a priority in the activity of Sister Teresa, the missionary of love.

Mother Teresa felt for the departing, fading life, but she was also interested in the life of newborns, especially those born in terrible conditions. She found it difficult to accept the plague of abandoning infants as well as older children, who were begging on the streets and had no chance for normal physical, mental and spiritual development. Together with her missionaries, Mother Teresa initially helped them in aid centers where children received food and medicines; later, she opened Children's Homes, where life from conception was protected. She accepted all abandoned children. Children found in the streets, sidewalks, dustbins, police stations and hospitals were given shelter by the Congregation. Among the Missionaries of Charity they found rescue, love, relief from the suffering and help in finding a home. Most of all, they received acceptance and closeness of the other person,

${ }^{22}$ Cf. M. di Lorenzo, Matka Teresa. Blaski miłości, op. cit., p. 56. 
because, as Mother Teresa claimed, to refuse to love a child, is like killing a child ${ }^{23}$.

Mother Teresa was also engaged in the fight against abortion with adoption, stressing that the life of each individual is the life of God in man, and nobody has the right to destroy it $^{24}$. She emphasized the inviolable sanctity of the life of children, which must be defended in any situation. Mother Teresa established a system of adoption, giving priority of adoption to Hindu families. This work was not always supported by the authorities, especially when the government followed the policy of limiting the growing population and forced sterilization was a common practice. Mother Teresa was accused of human trafficking, but she simply responded to these accusations that she was ready to adopt and raise every child ${ }^{25}$. Since the beginning of her work, Mother Teresa took care of the youngest and defenseless children. She treated, raised and taught children, was moved by the sight of abandoned children, orphans or children stigmatized because of their parents' disease. She treated them like the most beautiful gift of God that some people damage through their own selfishness and lack of respect for the divine work. The proof of her love for children are hundreds of photographs of children in her arms which show her moved and full of warmth face as well as enormous affection for these defenseless beings ${ }^{26}$.

The lepers constituted another group of people where Mother Teresa's work and love for the neighbor were realized. In the Hindu culture, leprosy caused great fear and was considered a divine punishment for sins. The disease led to the social exclusion of the sick, contempt of society, and even rejection by the family. Mother Teresa was not afraid of contracting the disease. She did not spurn

\footnotetext{
23 Cf. R. Allegri, Matka ubogich: rozmowa z Matka Teresq z Kalkuty, trans. B. Piotrowska, Kraków 2002, s. 107-111.

${ }^{24}$ Cf. M. di Lorenzo, Matka Teresa. Blaski miłości, op. cit., pp. 57-58.

25 Cf. G. de La Borie, Małe życie Matki Teresy, op. cit., pp. 71-72.

26 Cf. G. Łęcicki, Matka Teresa. Misjonarka Miłości i Miłosierdzia, Warszawa 1998, pp. 81-82.
} 
the "untouchables", although contacting with the people suffering from leprosy was considered as opposing the will of God. She tried to help the lepers, for whom, as she explained, Jesus died on the cross. Caring for the lepers, she changed the social attitude towards them, taught respect to these people and showed that they have the right to dignity, civilized living conditions, work, family and social belonging ${ }^{27}$. Sister Teresa started her campaign to combat leprosy in 1957 by organizing a mobile emergency unit with the medical and nursing care. At the same time, she explained to the locals that people infected with leprosy are also children of God. Two years later, she opened the first permanent leprosarium, dedicated to Mahatma Gandhi. The patients staying in the leper colony earned their living by growing pigs, goats, as well as producing sari and sandals.

Mother Teresa's dream was to create a real city for the lepers. The Indian government granted her a field to build the city in the area of Asansol. But Mother Teresa lacked financial resources to implement the plan. It was not until 1964 that she succeeded; she sold an American car donated to her by Pope Paul VI on an auction. The vehicle bore the inscription "To Mother Teresa, to share in her universal mission of love". The funds helped create Shantinagar, City of Peace, whose main street was called Paul VI Avenue. Soon, thanks to the granted prizes and donations, new districts, schools, gardens, shops and offices were built in the leper colony, creating a new, civilized world for hundreds of people marked by the disease ${ }^{28}$. She gave them everything the society denied; she liberated them from dirty ghettos and restored their humanity. The missionary changed the social attitude towards the leper patients, explaining that they are like other people and Jesus Himself. Despite the disfigurement of their bodies, they were wonderful people capable of love, as she said. For her and

27 Cf. M. di Lorenzo, Matka Teresa. Blaski miłości, op. cit., p. 63.

${ }^{28}$ Cf. ibid., pp. 64-65. 
her missionaries, helping the suffering lepers was another way of fulfilling the desire for love among people $e^{29}$.

Mother Teresa's Congregation also helped people suffering from AIDS, mental illnesses, drug addictions; people persecuted by various systems, also because of the color of their skin; prisoners deprived of their families; victims of the world's armed conflicts and disasters, as well as the oldest members of society, often doomed to loneliness because of the cult of youth in the Western countries ${ }^{30}$. In each of these people, she could see their deep distress and the need for support. Her caring attitude led to the creation of regional houses of the Missionaries of Charity, e.g. in Baghdad after the Gulf War, in Rotterdam, Venezuela and other places of the world, and everything in order to fulfill Christ's desire for love, which Jesus addressed to her in $1948^{31}$.

God further leads and supports the Congregation of the Missionaries of Charity, which has reached all continents, and the boundless love of Christ has begun to spread through the farthest corners of the world, starting with the poorest neighborhoods of Calcutta and a little hunched missionary. The small stature of Mother Teresa - her delicate posture, stooped due to the passing of time, her expressive face with watchful eyes - has become known in the world, and thanks to her simple acts, she has earned the nickname "great". As she claimed, she did not want to change the world; she was dreaming to be a drop of clear water reflecting the love of God. In this simple way, she explained that every human being bears a huge capital of love, which must be properly invested ${ }^{32}$. It's just so little and so much at the same time! Mother Teresa passed into the house of the Lord on June 5, 1997, and through all her life she wanted what is written on her modest tomb, "Love each other as I have loved you" (John 15:12). Moved by her

\footnotetext{
${ }^{29}$ Cf. E. M. Stone, Błogosławiona Matka Teresa. Życie w miłości, trans. I. Nowicka, Kraków 2003, p. 34.

${ }^{30}$ Cf. G. de La Borie, Małe życie Matki Teresy, op. cit., pp. 73-74.

31 Cf. Matka Teresa, Pójdź, bądź moim światłem, op. cit., pp. 65-66.

32 Cf. M. di Lorenzo, Matka Teresa. Blaski miłości, op. cit., p. 85.
} 
unique work, the Catholic Church adopted an accelerated procedure for the process of beatification of Mother Teresa, and on October 19, 2003, Pope John Paul II declared Mother Teresa blessed. Now, in 2016, Sister Teresa, the spokeswoman for the poor, the sick and the suffering, the great advocate of Love, will be canonized.

\section{Jesus Christ present in the sick and the suffering}

The Son of God, who became man, suffered immense suffering and gave his life for every person. Responding to this extraordinary gesture of love from God, each person should strive to be like Him and with compassion, hope and devotion approach the sick, the suffering, those in need of treatment and spiritual support. In this way, we create a space for Jesus Christ, who is present in the sick and the suffering. This is how Mother Teresa acted, bringing Christ to the poor, the needy and the doubting in times of painful trials. Throughout her life, she felt a spiritual union with $\mathrm{Christ}^{33}$. She understood a strong relationship of the suffering Jesus with the suffering of the poor and, as she emphasized, she did not love all the poor and suffering people taken together, but each man individually, as she could see the reflection of Christ in the face of every human being ${ }^{34}$. At the same time, she was a seeking person, amazed by the world and the surrounding reality, having her eyes wide open to the world around her and the glory of $\operatorname{God}^{35}$.

Mother Teresa tried to understand every person she met and help many people so that everyone could experience an ordinary human friendship and love, and thus feel the infinite love of the Lord; having approached Him, they could then love and serve $\mathrm{Him}^{36}$. She always set herself new challenges, and when she managed to arrange something for her patients - she was beaming with energy and joy. Mother Teresa tried to see only the good and beauty in all people and facts. When

33 Cf. X. Lecoeur, Matka Teresa. Niezłomna w wierze, op. cit., p. 30.

${ }^{34}$ Cf. M. di Lorenzo, Matka Teresa. Blaski miłości, op. cit., p. 115.

${ }^{35}$ Cf. L. Maasburg, Matka Teresa. Cudowne historie, op. cit., p. 67.

36 Cf. Matka Teresa, Pójdź, bądź moim światłem, op. cit., p. 67. 
the authorities granted her a building where she could take care of the sick and the suffering (a hospice for the poor), she was not put off by any obstacles or reluctance of local residents. She herself took the first patients into the building; in each of them, she could see a suffering man and the face of Christ. This is the approach she taught to her sisters. Regardless of the patients' faith or caste, she did not feel any disgust or aversion to the bodies of the sick, who were often smelly and covered with feces or vomit ${ }^{37}$.

The vast majority of patients had lived on the street before they came to the hospice; they were full of fear, sadness and terror. Receiving care, a smile, tenderness, peace, understanding, respect and love from the sisters, they got rid of fear, passed away with a smile and full of trust, thanking the sisters with words or a beautiful smile. As Mother Teresa frequently repeated - the hospice was also inhabited by God Himself ${ }^{38}$. The dynamically changing situation in Calcutta, the humane treatment of the sick, the suffering and the poor won the admiration even among the opponents of the sisters' service, who did not expect any praise and carried on with their work of "deepening" love. Even after a hard and exhausting work, they found the time for a common prayer in the chapel where they regained strength and desire to continue God's work. Mother Teresa often encouraged her sisters to an even harder ministry, deeper love and more generous service. Irrespective of the place of work, she required great and devoted care for the patients, punctuality, empathy for others as well as reminded the sisters to do so in the name of love stemming from their faith.

\footnotetext{
37 Warto w tym miejscu wspomnieć o kapłanie bogini Kali, który zachorował na gruźlicę i nie znalazł opieki wśród „swoich”. Zaoferowała mu ją natomiast Matka Teresa, co zjednało jej życzliwość pobratymców chorego i podziw dla działań sióstr na rzecz wszystkich potrzebujących. Matka Teresa i jej misjonarki nie potrafiły postępować inaczej, widząc wizerunek Chrystusa w każdym człowieku, traktowały ludzi jak braci i siostry, z szacunkiem, starając się nie uchybić ich godności. Cf. R. Allegri, Matka ubogich: rozmowa $z$ Matka Teresa $z$ Kalkuty, op. cit., p. 104.

38 Ibid., pp. 104-105.
} 
A special place in the heart of Mother Teresa was occupied by the already mentioned hospice Nirmal Hriday, which she called a living tabernacle of the suffering Christ. Therefore, she put special requirements on her sisters during their service there. The sisters always had to have clean hands when they nurtured the diseased bodies of the patients, use clean language when they spoke words of comfort, faith and love, because, as she pointed out, for most patients, this was their first experience of love, and, in many cases, the last one. She gave similar instructions to the sisters working at Siśu Bhawan, a home for the lonely, abandoned girls, mothers of unwanted children, so thirsty of warmth and love. It was in Siśu Bhawan where a new life began, so working with these mothers was even harder than working with the dying poor, the suffering or the lepers. These girls and women were the embodiment of Christ in poor clothes, according to Mother Teresa ${ }^{39}$.

The missionary was deeply convinced about the presence of Christ among the most needy, and, therefore, she encouraged all to recognize Him in every poor and suffering person, because only in this way can we release the enormous amounts of love, understanding and patience with others lying deep in our hearts. She taught that humans need each other, as a solitary life becomes barren and empty. She also passed on this truth to her sisters, stressing that we cannot speak of the love of God, if we do not love the people we live with under one roof and break the bread of life every day ${ }^{40}$. She regularly reminded the suffering and the sick of the joy of the Resurrection, comforting the poor and the rejected that Easter morning would dawn to each of them; she also prayed that God penetrated her body and filled her with the spirituality of His being ${ }^{41}$.

Such an attitude of Mother Teresa and her sisters came under some negative criticism as well. There were people who called her

\footnotetext{
39 Cf. K. Spink, Matka Teresa: autoryzowana biografia, trans. M. Grabska-Ryńska, Warszawa 2002, pp. 233- 240.

40 Cf. Matka Teresa, Jezus - kochany w najbiedniejszych z biednych, trans. M. Majdan, Warszawa 2001, s. 100.

41 Cf. ibid., pp. 62-63.
} 
"mad", but evaluating her work - we can only add that she was "mad in God", a person who all her earthly life devoted to the service to the poor in the name of Jesus, believing deeply in His presence in every human being in need. Mother Teresa saw Christ firmly and heard Him through the needs of the sick, the poor and the suffering; she focused on Him and realized His desire for love in every man: a drunk, a prostitute, the hungry, the naked, a lonely brother or sister. She repeatedly reminded her sisters about the need to pray individually to be alone with Jesus and, through their purified hearts, hear the voice of God in the poor ${ }^{42}$.

The sisters were satisfied with eating modest meals, wearing simple clothes or out-of-fashion shoes of various colors and styles, which aroused disbelief and, often, contempt. The world could not understand how the Missionaries of Charity could stay in hospital in a common room together with the poor of Christ, while they could easily get a solitary room. They were thought to be wasting their precious lives and destroying their own talents. From a reasonable point of view, it is hard to deny; yet, such an attitude makes sense if we can perceive Christ in His poverty.

Mother Teresa and her sisters chose a difficult path of service to Jesus. They wanted to find God in the most needy, gain strength from the helplessness and suffering of others, help, support and bring relief to others, thus receiving joy and deepening the desire for love spoken by Christ on the cross. Serving Jesus, they nurtured, fed, dressed and visited Him by meeting Him in every human being in need of love ${ }^{43}$, and claiming that true love must hurt. Mother Teresa emphasized that God has prepared and planned every person's individual path of life, which can only be read through prayer, while the most important task in taking this path is to boldly follow the voice of the Lord and carry out our vocation.

42 Cf. ibid., pp. 14-16.

43 Cf. Prosta Droga, ed. L. Yardey, Warszawa 1996, p. 31. 


\section{Suffering as a way of experiencing and fulfilling life tasks}

Accepting the pain and understanding the meaning of suffering is not easy even for a deeply religious Christian. Therefore, the Catholic Church faces an extremely difficult task of supporting man in his dilemmas and helping him understand that even a struggle with the suffering can bring out good, and that a person experiencing suffering has a chance to discover its hidden sense in such a difficult situation. The great and the small, sinners and saints, the rich and the poor, the young and the old - all suffer in their lives, and everyone in face of suffering anxiously poses the following question: Why has God allowed suffering? It should also be noted that a lonely person experiences greater suffering, a suffering that makes them seek escape from physical pain in the achievements of medicine and solace in faith, which brings the spiritual life ${ }^{44}$.

The sick and poor people in Calcutta usually could not afford treatment. The emergence of a disease very often meant helpless waiting for death in inhumane conditions. Such a situation deprived a human person of the will to fight, show grief, anger or objection; it created inner emptiness, where there was no God ${ }^{45}$. Mother Teresa had to face the difficult situation of the poor and sick people of Calcutta. The help offered to these people, the relief felt by the suffering and their finding faith in Christ was for her a sign, a gift and a proof that God loves with an infinite love, because without His help she would not be able to do anything.

Mother Teresa treated her own work and the work of her sisters as a means to deepen love and generosity, explaining that without the suffering, it would only be good, useful and necessary work, but work done without Christ, and it could not be an element of Redemption ${ }^{46}$.

\footnotetext{
44 Cf. J. Zieliński, W szkole cierpienia. Trudne drogi do ważnych odkryć, Kraków 2007, p. 5.

${ }^{45}$ Cf. P. Chetcuti, Wybierając służbą nędzarzowi, trans. M. Oktawa, Poznań 1985, pp. 11-13.

${ }^{46}$ Cf. J. Zieliński, W szkole cierpienia. Trudne drogi do ważnych odkryć, op. cit., pp. 18-20.
} 
She explained that the suffering experienced jointly by patients and by the sisters taking care of them is like a sacrifice, similar to the cup constantly filled by all the deep love that satisfies the desire of God. This gave rise to a deeply held belief among the sisters that their service to the poor was also the service done to the suffering Jesus. Therefore, Mother Teresa could not and did not want to be indifferent to the poor or the dying in the streets from hunger and disease. For her, working among the poor and the suffering became an instrument of God's love because the ministry to the lepers, the dirty, people who did not possess anything - brought the most precious gift of love, gratitude, joy and a smile, while the needy received acceptance, dignity and contact with another human being ${ }^{47}$.

The Missionaries of Charity believed that God identifies with the most needy and supports the hungry, the sick, the homeless and the suffering who require something more than money, bread, home or clothes, who need another person that would share their suffering with them. Mother Teresa satisfied their inner craving by showing them compassion, touching and hugging them, giving them love, and repeating, at the same time, that if a man turns away from his neighbor, he turns away from Christ Himself. She asked the rich to serve Christ by helping the poor. She assured the sick, the suffering and the poor of the joy she gained from meeting them and the opportunity to help them ${ }^{48}$. It is the poor that gave her strength, taught her patience and perseverance, let her join in the Passion of Christ through their own suffering which she considered the most beautiful gift for man and a sign of His love ${ }^{49}$.

While the world often rejected her vision of suffering, Mother Teresa believed that a happy person is the one who can show the beam of the divine light in a life often marked by incomprehensible

\footnotetext{
47 Cf. ibid., p. 51.

48 Cf. K. Spink, W ciszy serca. Medytacje i modlitwy Matki Teresy, trans. K. Kołodziejczyk, Warszawa 1988, pp. 16-17.

49 Cf. Dzieło Matki Teresy z Kalkuty, trans. I. Moraczewska, A. Szymanowski, Warszawa 1985, pp. 11-12.
} 
suffering that is difficult to accept. She confirmed this through her deep concern and care for the sick, which some people found unreasonable ${ }^{50}$. She became an example for other people, teaching that the suffering can be a blessing; that the love of Jesus should be based on two great commandments: love of God and love of neighbor; that we should love and accept every person that God has put in our way; that compassion for the suffering people is our duty, because only then will we come close to the mystery of the suffering of our neighbor, and will we be able to give ourselves to him and receive something for ourselves as well ${ }^{51}$. For Mother Teresa, the suffering became something very common over time, since she could see that the suffering does not miss any man and is a kiss of God and a gift that allows us to understand the passion of Christ ${ }^{52}$.

Despite the suffering surrounding the life of Mother Teresa, she was a very joyful person ${ }^{53}$. She did not understand people who could not enjoy life. Her own joy, which she passed on to all her missionaries, allowed her to treat the suffering of neighbors as challenges that need to be undertaken to reach God. The disease makes it easier to look at a human being without idealizing him $^{54}$. Joy was also evidence of her devotion to God even when she was experiencing a dark night of the spirit. She strived to overcome everything that might cause grief and helped her missionaries forget about the fatigue and difficulties that had to be faced every day to reach the needy ${ }^{55}$. She was a devoted and generous person, forgetting about herself and trying only to please

\footnotetext{
50 Cf. Siostra Małgorzata, Matka Teresa Misjonarka Miłości, Kraków 2000, pp. 84-87.

51 Cf. K. Spink, Łańcuch miłości. Matka Teresa i jej cierpiący uczniowie, trans. I. Doleżał-Nowicka, Warszawa 1987, s. 24-25.

52 Cf. Matka Teresa z Kalkuty, Miłość, owoc, który dojrzewa w każdym czasie. Rozważania na każdy dzień, trans. H. Bramska, Warszawa 1991, pp. 67-68.

53 Cf. C. Siccardi, Matka Teresa. Wszystko zaczęło się w mojej ziemi, trans. K. Stopa, Pelplin 2010, p. 87.

${ }^{54}$ Cf. T. Bosco, Najpiękniejsze myśli Matki Teresy, trans. D. Torz, Warszawa 2004, p. 60 .

55 Cf. J. Langford, Matka Teresa. Ukryty ogień, trans. P. Chołda, Kraków 2010, p. 147.
} 
God alone. As she often emphasized, this joy stemmed from her love to all who fulfilled the passion of Jesus in their bodies ${ }^{56}$.

Conclusion Mother Teresa served the people and God, helped the poorest of the poor and worked very hard in the slums of Calcutta, where she gave a great and infinite love to others by living with God and seeing Him in every person ${ }^{57}$. She never tried to force anybody to anything; she only strived to spread the civilization of love. She was a true missionary, had a big heart for everyone, regardless of their faith or religious affiliation. And there is no contradiction in this, because both attitudes are closely related and show the strength of Mother Teresa ${ }^{58}$. The suffering touches the human being very deeply in all its complexity, both physically and spiritually. Although the suffering is perceived as a destructive force, it can be experienced in a creative way, and, consequently, lead to a union with God. Whether this happens or not depends on one's personal relationship with God, and the ability to read the message flowing from the cross of Christ and the perception of one's own self.

The example of Mother Teresa of Calcutta, still present among people through the service of her sisters, shows us how to follow the evangelical approach towards the suffering man, who deserves respect and dignity, who should not be marginalized or treated objectively. The choice of one's individual path, however, is a matter of personal preference, and requires a thorough reflection, and, sometimes, also some advice. Although the path of her life consisted of some difficult experiences, she was able to, in cooperation with God's grace, develop effective ways of dealing with them. Her struggle with the evil and selfishness is becoming a cure for the contemporary Christians and an example of path worth following in order to experience spiritual fulfillment and a sense of one's life vocation. This extraordinary

\footnotetext{
56 Cf. C. Siccardi, Matka Teresa. Wszystko zaczęło się w mojej ziemi, op. cit., pp. 92-93.

${ }^{57}$ Cf. J. Langford, Matka Teresa. Ukryty ogień, op. cit., p. 66.

58 Cf. L. Maasburg, Matka Teresa. Cudowne historie, op. cit., p. 177.
} 
missionary can become a model for many people of different faiths and beliefs.

\section{Bibliography:}

Allegri R., Matka ubogich: rozmowa $z$ Matka Teresa $z$ Kalkuty, transl. by B. Piotrowska, Kraków 2002.

Białkowska M., Świętość bez kompromisów, www.przewodnik-katolicki. pl/Archiwum/2010/- Przewodnik-Katolicki-34-2010/Wiara-i-Kosciol/ Swietosc-bez-kompromisow.

Bosco T., Najpiękniejsze myśli Matki Teresy, transl. by D. Torz, Warszawa 2004.

Chetcuti P., Wybierając stużbą nędzarzowi, transl. by M. Oktawa, Poznań 1985.

De La Borie G., Małe życie Matki Teresy, transl. by J. Jędraszak, Ząbki 2003.

Dhavamony M., U źródeł duchowości Matki Teresy; teologiczna perspektywa, transl. by K. Bronk, Kraków 2002.

Di Lorenzo M., Matka Teresa. Blaski miłości, transl. by M. Kubiak, Poznań 2004.

Dzieło Matki Teresy z Kalkuty, transl. by I. Moraczewska, A. Szymanowski, Warszawa 1985.

Gjergji L., Matka Teresa, transl. by A. Spurgjasz, Litonova 1994.

Gjergji L., Matka Teresa. Miłość w czynach, transl. by J. Kupka, Warszawa 2002.

Langford J., Matka Teresa. Ukryty ogień, transl. by P. Chołda, Kraków 2010. Lecoeur X., Matka Teresa. Niezłomna w wierze, transl. by E. Bekier, Warszawa 2006.

Łęcicki G., Matka Teresa. Misjonarka Miłości i Miłosierdzia, Warszawa 1998.

Maasburg L., Matka Teresa. Cudowne historie, Poznań 2010.

Matka Teresa z Kalkuty, Miłość, owoc, który dojrzewa w każdym czasie. Rozważania na każdy dzień, transl. by H. Bramska, Warszawa 1991.

Matka Teresa, Jezus - kochany w najbiedniejszych $z$ biednych, transl. by M. Majdan, Warszawa 2001.

Matka Teresa, Pójdź, bądź moim świattem, ed. by B. Kolodiejchuk, Warszawa 2007.

Matka Teresa, Radość z kochania. Przewodnik życia duchowego na każdy dzień roku, transl. by A. Kieturakis, Białystok 1997.

Murray P., Matka Teresa. Kochałam Jezusa w ciemnościach, Łódź 2010. 
Prosta Droga, ed. by L. Yardey, Warszawa 1996.

Siccardi C., Matka Teresa. Wszystko zaczęło się w mojej ziemi, transl. by K. Stopa, Pelplin 2010.

Siostra Małgorzata, Matka Teresa Misjonarka Miłości, Kraków 2000.

Spink K., Łańcuch miłości. Matka Teresa i jej cierpiący uczniowie, transl. by I. Doleżał-Nowicka, Warszawa 1987.

Spink K., Matka Teresa: autoryzowana biografia, transl. by M. Grabska-Ryńska, Warszawa 2002.

Spink K., W ciszy serca. Medytacje i modlitwy Matki Teresy, transl. by K. Kołodziejczyk, Warszawa 1988.

Stone E. M., Błogosławiona Matka Teresa. Życie w miłości, transl. by I. Nowicka, Kraków 2003.

Zieliński J., W szkole cierpienia. Trudne drogi do ważnych odkryć, Kraków 2007. 